\title{
Minha experiência na Vernáculo
}

Francielle de Souza ${ }^{1}$

A oportunidade de participar da organização da Revista Vernáculo apareceu em 2013, quando Hilton Costa me convidou para uma reunião que discutiria o futuro da revista. Me interessei porque percebi que me envolver nesse projeto traria novas experiências pra minha graduação. Escolhi trabalhar com a revisão do material que chega para publicação: com o número pré-montado, é feita a leitura de todos os artigos e impressões de leitura para verificar a correção de português e fazer algumas observações sobre a formatação dos arquivos.

Entrar em contato com pesquisas (feitas ou em andamento) através desse material é um processo muito interessante, pois proporciona o contato com diversos tipos de assuntos que estão sendo abordados hoje em dia na pesquisa acadêmica em História (e que talvez eu não conheceria por outros meios); além de apreender as instituições em que tal ou tal assunto recebe um tratamento privilegiado, usufruindo de uma maior quantia de pesquisadores interessados. Ao ver

\footnotetext{
${ }^{1}$ Graduanda em História - Bacharelado e Licenciatura - pela Universidade Federal do Paraná desenvolve pesquisas sobre História do Brasil Colonial, com foco na História indígena e hierarquias sociais.
} 
pesquisadores iniciantes explorando os resultados de suas primeiras investigações, e talvez publicando pela primeira vez, como foi meu caso, compreendo o quão importante é publicar artigos nessa altura da formação acadêmica: não apenas para constar no lattes, mas também como oportunidade de aprender a escrever em um determinado formato, organizando e relacionando os dados mais relevantes da pesquisa. Formato esse que aparece constantemente na jornada acadêmica.

Percebo por conta disso, a importância da Revista Vernáculo em continuar se preocupando em publicar trabalhos de graduandos, mestrandos e doutorandos, contribuindo diretamente com a qualidade da formação de pesquisadores.

É com muita alegria que vejo a Vernáculo com seus números em dia e muita satisfação de ter colaborado para isso de alguma forma. É um orgulho fazer parte dessa equipe! Que venham muitos anos pela frente! 